\title{
Women and Glass Ceiling in Albania
}

\author{
Elda Dollija, Phd candidate \\ University "Fan S. Noli", Korce, Department of Management \\ Tel. 00355672199921 \\ eldacollaku@yahoo.it \\ Manjola Çollaku \\ "Beder University", Tirana, Department of Psychology \\ Tel. 0035594702329 \\ manjola_collaku@hotmail.com
}

Doi:10.5901/mjss.2013.v4n9p720

\section{Abstract}

Concerns about gender equality are disciplined in Constitution, and more and more national and international acts, laws and directives. Anyway, if we have a look at statistics, the literature review, a lot of studies and researches in different countries, women's career progression has not kept pace with that of men's. Even though women represent $44 \%$ of the labor force in Albania they continue to lag behind male counterparts in reaching upper level positions. Women's career progression into executive-level positions continues to lag behind that of their male counterparts in both the private and public sectors (D'Agostino \& Levine, 2009). If we have a quick look at high level of state government such as president, prime minister, ministers, etc. it is very hard to find a woman on top o these and other institutions. The same thing happens in private sector, for example the banking or in telecommunicating sectors, which are through the most important sectors of the economy of Albania, it is very hard to see a woman on their top (only 2 CEOs women in banking sector and no CEO woman in telecommunicating sector). Why does this happen? When women try to reach high levels of management and leadership positions, they face with the phenomenon of "Glass ceiling" which impedes them in reaching those positions.

Keywords: glass ceiling, women, Albania, barriers

\section{Introduction}

The recent years have been marked by the increasing participation of women in the labor force internationally (Cooper, 1996a, p. 21; Wentling, 2003, p .311). In Albania the participation of women in the labor force is $44 \%$. A large number of these women are still found in the agriculture sector and the informal sector of industry. The question to ask is how many women actually hold positions of power in top management, and the reality is very few. The situation is particularly true for the commercial banking industry in Albania where the number of women professionals in senior executive management positions (for example CEO's, deputy CEO's, company board members) is minimal compared to that of men. According to Cooper (2001), "The reasons for this difference are varied in nature and often referred to as 'barriers' or 'obstacles' that women face in the advancement of their careers. These barriers are often based on the factors of gender and race, and not aspects such as the lack of ability to handle jobs at higher institutional levels". (p. 31).

\section{Barriers to women career progression - Glass ceiling}

The barriers that prevent women from ascending to senior management positions and in high level decision making positions, in large corporations and public sector have often been described collectively by the metaphor "the glass ceiling". The glass ceiling is defined as "a barrier so subtle that it is transparent, yet so strong that it prevents women from moving up in the management hierarchy" (Morrison \& Von Glinow, 1990). Wirth (2001) defines the Glass Ceiling as "the invisible artificial barriers, created by attitudinal and organizational prejudices, which block women from senior executive positions".

The "glass ceiling" has consequences not only for the women themselves, but also for the organizations they work, for their reputations and their ability to maximize their productivity and growth and for the whole society. Companies and 
societies cannot afford to waste the full potential of half of their workforce and undermine their competitiveness. Rather, they need to capitalize upon the skills of women, valuing and encouraging women's professional growth and development. Moreover, they must create a business culture and society that supports innovation and high performance, which requires many different people with diverse talents and thinking styles (Accenture, 2006).

Past studies have identified several pervasive barriers to the appointment of women to senior professional positions, including working practices, tradition and attitudes, pay differentials, stereotyping, and a lack of both informal networks and "in line positions" (D'Agostino and Levine, 2009; Dreher, 2003; Rogier \& Padgett, 2004; Catalist, 1993; Accenture 2006). Other studies have divided these barriers into three categories: individual barriers; societal barriers and organizational barriers (Cooper, 1996a; Oakley, 2000; Cross, 2009; Maheshwari, 2012). Their findings led them conclude that the glass ceiling still persists: women are underrepresented in top-level administrative and professional positions in distributive and regular agencies.

\section{Individual Barriers}

Women's awareness toward their career paths is an important factor (Cooper, 2001). Although they are qualified as their male counterparts, sometimes they need to work harder and perform better to obtain senior positions (Maddock, 2002). Women describe self-limiting beliefs and lack of self-confidence, which can result in them delaying going forward for promotion until they feel completely ready, have strong evidence of all the competencies and are confident that they will be successful. They are more modest about their skills and achievements and need to have confidence in their own skills and abilities before applying for new roles. As a result women try to thoroughly research the role and critically assess their own competence before applying. In comparison a man will be much more likely to thrown their hat into the ring and 'give it a go', even if they are not confident of the outcome. It is described that their approach is to tick off 5 of 10 criteria and consider this is enough to have a go, whereas a woman will wait to gather experience of all 10 criteria before applying. Klerks and Brown (2004) similarly found that going for high rank is demanding and failure disappointing, so women may over prepare or hold back.

According to Cooper (2001), there is a common perception that men are leaders and women are the supportive followers. This perception of women as followers is strengthened by a lack of strong female role models. In an environment where the number of women in key executive positions is minimal, it is difficult to develop a mental model of women as leaders. This inhibits self-perception and evaluation of a woman's potential to be a leader.

Another individual barrier to women career progression is the role stress due to multiple role demands inherent in running a career while also running a home and family (Cooper, 1996b). In the long run, the success for these women is often at substantial cost to their personal lives. Due to demanding job, they have to work long hours and may have to forgo long-term relationships and the opportunity to have children if they wish to progress to the top of the profession.

\section{Societal barriers}

At the root of the issue of women in management is possibly the role ascribed to women by society at large. Women have been seen as basically the nurturers of the family and men as the breadwinners (Cooper, 1996b). As bearers of the scarcer resource, men hold the power strings. This seems to be true across cultures and across time. According to Oakley (2000), explanations for the extremely low number of women in the position of CEO and other senior management positions go beyond corporate policies and practices and also embrace the impact of gender-based behavioral dynamics such as:

- behavioral double binds (a behavior norm that creates a situation where a person cannot win no matter what she does);

- women's communication styles (women's communication styles are often misinterpreted or devalued by men, and the less aggressive and assertive forms of communication associated with females may be particularly unacceptable ways to communicate in the upper echelons of most corporations);

- gender-based stereotypes (stereotypically men were seen as being aggressive, independent, unemotional, objective, dominant, active, competitive, logical, worldly, self-confident, and skilled in business, all competence-related traits. Women were stereotypically seen as exhibiting the opposite traits of males on all the competence-related traits, indicating that stereotypically feminine traits are associated with incompetence);

- preferred leadership styles (the cultural stereotype of leaders is male, and presents a formidable barrier to any woman who aspires to a leadership position, especially a position like CEO); 
- old boy networks (informal networks help men advance more than women because they are closed to females, and women have great difficulty in accessing and utilizing their possible potentials).

\section{Organizational barriers}

In addition to individual and societal barriers, when working in organizations (private and public ones), women have to face other barriers related to the corporate culture, climate and practices. Work organizations have traditionally been created and run by men. They have accordingly assumed masculine structures often supported by deeply felt values (Cooper, 1996a). Linehan et al. (2001) mentioned that many jobs are still seen as men's or women's jobs and this influences the initials of a particular gender to organizations. The GOS (Gender Organizational Structure) model of gender diversity explains the status and experiences of women (and men) in organizations across organizational culture and organizational structure (Cooper, 2001). Specifically, includes informal networking, diversity, performance evaluations, stereotyping, and preferred leadership. According to Fagenson (1993) and Cooper (2001) organizational structure impedes women's entry to and advancement in the workplace. That structure can include job recruitment, job assignment, mentoring, retention, training, how work and family are balanced by employees, and promotion and reward systems. Moreover, Bajdo and Dickson (2001) found that the greatest predictor of the number of women in management positions resulted from organizations that focus on aspects of organizational culture relating to gender equity practices.

\section{The status of women in Albania}

Legal frameworks and institutional mechanisms: Albania's gender legislation and policy reflect the steps taken in the framework of accession to the EU (European Union) and the Albanian government has developed a comprehensive legal and institutional framework for the promotion of gender equality and the protection of women's rights. In recent years, a number of significant achievements have been made by the Government of Albania (GoA) to move towards a more proactive implementation of the standards and norms laid out in the UN (United Nations) Convention on the Elimination of all forms of Discrimination Against Women (CEDAW), in the Beijing Platform for Action, in the Millennium Development Goals (MDGs), and in EU directives and policies addressing gender equality. The legal framework was established through the adoption of the law "On Measures against Violence in Family Relations" (No. 9669, dated 18.12.2006), the law "On Gender Equality in Society" (No.9970, dated 24.07.2008), and the Law "On Protection against Discrimination" (No. 10221, dated 04.02.2010). In Albania's most comprehensive policy document addressing gender equality and violence against women - the National Strategy on Gender Equality and Domestic Violence 2007-2010 - the GoA clearly states the key priorities for advancing women's human rights and ensuring gender equality. The revised framework, the National Strategy on Gender Equality, Gender-Based Violence and Domestic Violence 2011-2015, foresees as an explicit outcome of its first strategic goal the compilation of "updated data and information on progress regarding the status of men

Gender Inequality Index: Between 2002 and 2008, the Gender related Development Index, which describes inequality between women and men related to literacy, life expectancy, and education, increased from 0.771 to 0.816 , reflecting progress in these areas. However, inequality between women and men is multidimensional and therefore requires more composite measurement. Towards this end, the Gender Inequality Index (GII) was introduced in 2010. GII reflects inequality between women and men regarding education, reproductive health, empowerment, and the labor market. Between 2006 and 2010, improvement in these areas was evident in Albania, mainly because of the increased proportion of female students, higher number of women in diplomatic service, and some improvement in women's salaries. The gender inequality index in 2011 is 0.271 . Albania's 2011 Global Gender Gap Index ranking is 0.6748, placing it in 78th place (out of 135 countries) (National Report on the status of women and gender equality in Albania, 2011).

Gender wage gap: Through various laws, Albanian legislation regulates wages in the public sector, and article 115/1 of the Labor Code of the Republic of Albania (law no. 7961) explicitly refers to equal pay for women and men for work of equal value. In all education categories, women receive lower monthly wages, and women's average salary is 17.63 per cent lower than that of men with the same educational attainment (Miluka, 2011). For this phenomenon two main reasons may be given: First, women still continue to find employment primarily in the social state service sector, where in general, men predominantly occupy positions in law-making, high-level offices, and in management. Women act as specialists, regular workers and clerks in the education, health care and public administration sectors. Occupational segregation creates wage differentials by putting downward pressure on wages for occupations that are overcrowded by 
a particular sex and where labor supply is readily available. As a result of this occupational segregation, and a surplus of women seeking work in these sectors, women's wages are lower.

Second, the lack of support and limited provision of state care makes women the primary caregivers of children, the sick and the elderly. Due to women's child-bearing and caring responsibilities, the female labor force is therefore characterized by discontinuity of employment, especially during the childbearing ages, resulting, on average, in five years less experience over the course of working life, when compared to men. This additionally and negatively affects on women's position on the labor market. Women are at greater risk of being fired from work, or less likely to be employed and to retain their jobs, particularly at the child-bearing ages. Another factor that impacts women's low level of remuneration is also their low involvement in self-employment private activities.

Gender entrepreneurship and employment: Low access to credit and property and a lack of supporting policies promoting women's entrepreneurship, have accounted for a relatively low number of women entrepreneurs. Officially, women own $25.7 \%$ out of 106477 business in the country. As can be seen in figure 1, women have set up their businesses mainly in economic areas like commerce, wholesale and retail; in various services such as dentistry, legal services, hairdressing; agro-business, diary production, textile production, publishing, dressmaking, and handicrafts production. According to INSTAT, $18 \%$ of private business managers are women and only $31 \%$ of total value of business credit is taken by female entrepreneurs.

Figure 1: Percentage of entrepreneurs disaggregated by sex and sector

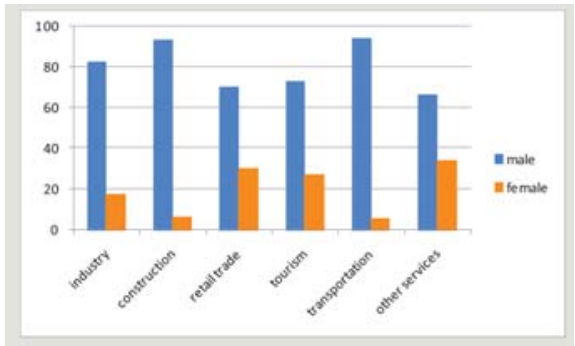

Source: METE, 2010

According to the National Institute of Statistics (INSTAT), females represent nearly half of the population and consist of about 44 percent of the active labor force in Albania. But this parity is not reflected is different aspects of economic and social life of women and men in Albania. As we can see from chart 1, women are more employed in agricultural private sector and less in non-agricultural private sector. On the other hand, even though women and men are nearly equally employed in public sector, according to the latest survey of the Department of Public Administrate (DPA) men are the directors and women support them.

Figure 2: Gendered employment structure by sector

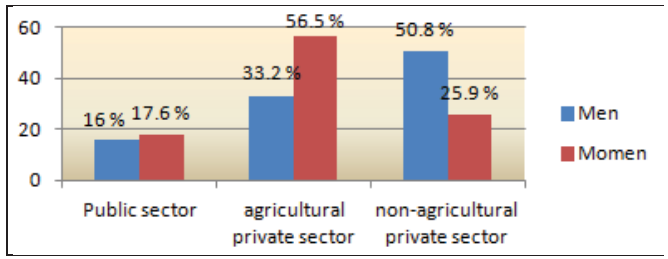

Source: INSTAT, 2012

Political Representation and Equal Participation in both Public and Private Decision-making: Women's representation and participation in decision making are key indicators of a society embracing equality between the sexes in all walks of life. Marked inequalities rest on the notion of deeply stereotyped models for women, girls, men and boys 
which assign authority, public agency and power to a predominantly male actor. In line with the law on Gender Equality in Society and CEDAW article 5, Albanian institutions are obliged to take all appropriate measures to modify or abolish existing laws, regulations, customs and practices that constitute and/or result in discrimination against women, including social and customary practices that are based on the idea of women's inferiority.

Even in sectors with a high percentage of female staff, women occupy primarily lower positions, and are generally absent from higher management levels. One of the key factors resulting in such pyramidal patterns is women's and men's socialization along traditional gender stereotypes and gender roles. Women are conceptualized as mothers and primary caregivers, while men are assigned expertise, competence and decision-making power in public life. This in turn leads to women occupying lower and lower-paid positions, which offer fewer career advancement and promotion opportunities; it also leads to the isolation of women in higher ranks. It reinforces male's dominant roles and the lack of representation of issues and topics relevant to women in planning and decision-making.

The traditional working patterns of many political parties and government structures continue to be barriers to women's participation in public life. However, the increased presence of women in politics and decision-making positions in government contributes to the redefining of political priorities and places new items on the political agenda. They reflect and address women's gender-specific concerns and also provide new perspectives on mainstream political issues.

In fact, we are all witnessing the lack of women equally participation in high level decision-making positions. Looking at table 1, we can see that Albanian's president is a man (and it has never been a woman); this is the first time we have a woman at the head of the Assembly; Chief Prosecutor, Governor of the Bank of Albania and the Prime Minister are men; only one out of 15 ministers is a woman; despite the initiative of increasing the number of women in the Assembly, only $16 \%$ of the deputies are women; only 2 out of 10 directors of Regions are women; only 3 out of 62 head of Municipalities are women and only 2 out of 306 Communities are women.

Table 1: High level decision-making positions

\begin{tabular}{|l|c|c|}
\hline & Men & Women \\
\hline President & 1 & 0 \\
\hline President of the Assembly & 0 & 1 \\
\hline Chief Prosecutor & 1 & 0 \\
\hline Governor of the Bank of Albania & 1 & 0 \\
\hline Prime Minister & 1 & 0 \\
\hline Minister & 14 & 1 \\
\hline Deputy & 120 & 20 \\
\hline Region & 10 & 2 \\
\hline Municipalities & 62 & 3 \\
\hline Communities & 306 & 2 \\
\hline
\end{tabular}

Source: Authors' survey

Evidence suggests that companies with a strong female representation at board and top management levels perform better than those without, and that gender-diverse boards have a positive impact on performance (McKinesy \& Company, 2007). It is also clear that boards make better decisions when a range of voices, drawing on different life experiences, is heard.

Despite increasing discussion of women's equal representation and efforts in raising the number of women in decision-making positions in the public and political arenas, in Albania, women's representation in leadership positions at private companies has not yet become an issue. Little is known about their representation as executives, heads of companies or members of managing boards. So, if we have a look at figure 3, which shows the presence of women in the hierarchy of commercial banks in Albania, when we go up the hierarchy, the percentage of women participating in high level decision making positions gets lower. Only 2 out of 16 CEOs are women. In telecommunicating sector, there is no woman CEO. There are not exact official figures, but the number of women leading corporate in Albania is very low.

Figure 3: The participation of women in the hierarchy Banking Industry 


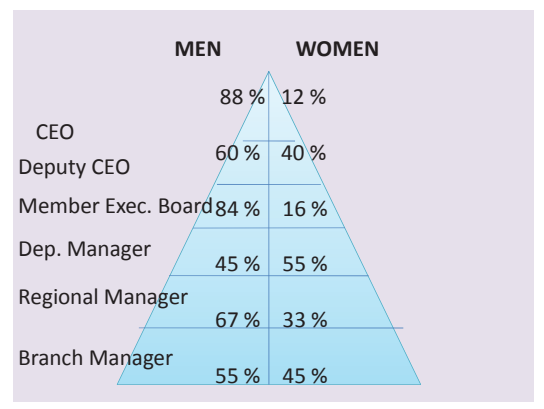

\section{Source: Authors' survey}

In parallel, the national legal and policy framework in Albania addresses several aspects that bear high relevance for efforts made to increase the percentage of women in business. Provisions include the following:

- The creation of equal opportunities for women;

- The establishment of family friendly policies (flexible working hours, parental leave for men and women, child care facilities, etc.);

- Enforcement of anti-discrimination legislation at the workplace;

- Implementation of sexual harassment policies;

- The provision of education to combat sexual harassment, in order to promote a climate of respect within a company;

- Integrated packages that support career advancement for women.

\section{Conclusions and Recommendations}

The numerical increase in women's representation - be it in political or government and in top of managerial hierarchyis an achievement in itself. However, in order to ensure the sustainability of efforts, activities must be accompanied by career development and advancement efforts for women. Specific and gender-sensitive measures are required in order to guide, coach and support the processes and dynamics of related organizational change.

Further investigation is required on the prevalence of women in high level positions in private business; their particular career patterns, networks and needs; and the identification of entry points for increasing their share in maledominated environments. Due to women's general higher educational attainment, they represent a significant human resource base for Albania's economy. Furthermore, promoting women to boards contributes to an increased talent pool that is available to a company.

Innovative approaches with proven results taken by companies to address the recruitment, development, and advancement of all managerial women should be awarded. An annual Albanian award would provide the business community with replicable models in order to help corporations and professional enterprises create pro women and family-friendly policies and initiatives that are beneficial for women and good for businesses. As a first step, the systematic aggregation of precise information on women in professional and managerial positions is required, on which to base further involvement and action. In line with the increasingly common EU practice, companies should be required to disclose each year the proportion of women on their board, the number of women in senior executive positions, and the number of female employees.

\section{References}

Accenture (2006), The anatomy of glass ceiling: barriers to women's professional advancement, available at: www.accenture.com

Catalist (1993), Successful Initiatives for Breaking the Glass Ceiling to Upward Mobility for Minorities and Women, http://digitalcommons.ilr.cornell.edu/key workplace

Cooper J. J. (1996) a. Perspectives on Career Development of Women in Management. Equal Opportunities International, 15, 30-41.

Cooper J. J. (1996) b The impact of work-family policies on women's career development: Boon or bust? Women in Management review $11(1), 5-19$ 
Cooper J. J. (2001). Women Middle Manager's Perception of the Glass Ceiling. Women in Management Review, 16, 30-41.

Council of Europe (n.d.) European Convention on Human Rights. Impact in 47 Countries. Country information: Albania, http://humanrights-convention.org/impact-of-the-european-convention-on-human-rights/

Cross, C., (2009), Barriers to the executive suite: evidence from Ireland, Leadership \& Organization Development Journal, 31 (2), $104-$ 119

D'Agostino, M.J., \& Levine, H., (2010), The Career Progression of Women in State Government Agencies, Gender in Management: An International Journal, 25 (1), 22-36.

Decision of the Council of Ministers No. 334 (17.02.2011).

Dreher, G.F., (2003), Breaking the glass ceiling: The effects of sex ratios and work-life programs on female leadership at the top, Human Relations, 56(5): 541-562:

European Commission. Database on women and men in decision-making. http://ec.europa.eu/social/main.jsp?catld=764\&langld=en

Fagenson, E.A. (1993), "Diversity in management: introduction and the importance of women in management", in Fagenson, E. (Ed.), Women in Management: Trends, Issues, and Challenges in Managerial Diversity, Sage, Newbury Park, CA

Government of Albania / United Nations (2010) 'Albania national report on achieving progress towards the Millennium Development Goals, Tirana, July 2010, http://www.un.org.al/editor-files/file/Albania\%20National\%20MDG\%20Report\%20-\%20July \%202010.pdf

http://www.mckinsey.com/locations/swiss/news_publications/pdf/women_matter_english.pdf

Klerks, N. and Brown, J (2004). Senior Police Women: Experiences in and perceptions of management and leadership. Research Report, University of Surrey.

Linehan M., H. Scullion, and J. S.Walsh. 2001. Barriers to women's participation in international management. European Business Review, 13 (1): 10-18.

Maddock, S., (2002), Modernization requires transformational skills: The need for a gender-balanced workforce. Women in Management Review, 17(1), 12-17

Maheshwari, K., (2012), The Glass Ceiling impact on Indian Women Employees, National Conference on Emerging Challenges for Sustainable Business 2012

McKinsey \& Company (2007). Women Matter: gender diversity, a corporate performance driver.

Miluka, J., 2011. Gender Wage Gap in Albania. Tirana: UN Women.

Ministry of Labor, Social Affairs and Equal Opportunities (MoLSAEO), United Nations Entity for Gender Equality and Empowerment of Women (UN Women), The National Report on the status of Women and Gender Equality (NRSWGE) in Albania

Morrison, A.M., \& Von Glinow, M.A., (1990), Women and minorities in management, American Psychologist, Vol. 45 pp. $200-208$.

Ragins, B.R., Townsend, B. \& Mattis, M., (1998), Gender gap in the executive suite: CEOs and female executives report on breaking the glass ceiling, Academy of Management Executive, Vol. 12 No. 1, pp. 28-42.

Republic of Albania, Albanian Constitution (1998).

Republic of Albania, Albanian Family Code, Law No. 9062 (2003).

Republic of Albania, Albanian Labour Code, Law No. 7961 (1995).

Republic of Albania. "Law on Gender Equality in Society" No. 9970 (2008).

Republic of Albania. "Law on Measures against Violence in Family Relations" No. 9669 (2006)

Republic of Albania. National Strategy for Social Inclusion 2007-2013.

Republik of Albania. Law No. 10221, "On Protection against Discrimination" (2010).

Rogier, S.A., \& Padgett, M.Y., (2004), The impact of utilizing a Flexible Work Schedule on the perceived career advancement potential of women, Human Resource Development: Quarterly, 15(1)

United Nations Development Programme (2011) Human Development Report 2011, available athttp://hdr.undp.org/en/media/ HDR_2011_EN_Complete.pdf

United Nations Treaty Collection (UNTC) (2010): Convention on the Elimination of All forms of Discrimination Against Women, countries ratified. - CEDAW: http://treaties.un.org/Pages/ViewDetails.aspx?src=TREATY\&mtdsg_no=IV-8\&chapter=4\&lang=en

Wentling R.M. (2003). The career development and aspirations of women in middle management - revisited", Women in Management Review, 18. 6. 311-24.

Wirth, L., (2001), Breaking through the glass ceiling: Women in Management, International Labor Office, Geneva.

World Economic Forum (2011) The Global Gender Gap Report 2011, available athttp://www3.weforum.org/docs/ WEF_GenderGap_Report_2011.pdf 